\title{
Article
}

\section{The Yield Stress of a Soft and Water Swellable Microgel Aqueous Suspension in Semi-Dilute Regime}

\author{
Isamu KANEDA \\ Material Science Research Center, Shiseido Co., Ltd. \\ 2-2-1, Hayabuchi, Tsuzuki-ku, Yokohama 224-8558, Japan
}

\begin{abstract}
The rheological properties and the morphology of a water swellable microgel developed as a viscosity thickener for cosmetics were studied. The water swellable microgel was synthesized by a novel inversed microemulsion polymerization technique. The apparent yield stress appeared in semi-dilute regime, at around twice the overlapped concentration of the microgel and the value of the apparent yield stress increased with the concentration of the microgel. Although the deformation behavior of the microgel suspension at very small shear stress looked like elastic deformation from its flowcurve, it was revealed the suspension flowed in such case by creep measurement. It is implied that there would be a structure causing quite slow relaxation by creep and dynamic modulus measurements. The morphology of the microgel through the freeze-fracture TEM showed the microgel was swollen as a spherical shape and closely packed at a concentration at which the apparent yield stress appeared. One possible mechanism of the appearance of yield stress is the friction between the layers where the microgel particles arrange in a random closed packing state.
\end{abstract}

Key Words: Viscoelasticity / Polymer blend / Physical gel / Suspension /

\section{柔らかい水膨潤性ミクロゲルの準希薄分散液の降伏応力の評価}

金田勇

(原稿受理 : 2005年11月24日)

1. 緒言

化粧品原料の中でも増粘剤は最も重要な原料の一つであ る．増粘剤は製品の粘度調整のみならず，化粧品の使用感触 の調整にも大きく影響を及ぼす。化粧品は啫好性の高い工業 製品であり，消費者の好みに応じた製品特性が求められる. 大げさに言えば十人の消費者には十通りの好みがあると 言っても過言ではない. したがって化粧品技術者は多様な消 費者の嗜好にマッチ寸る増粘剤を取り揃えて, 化粧品の処方 開発を行わなければならない.

水系増粘剤としてはもっぱら水溶性高分子, 具体的にはポ リアクリル酸, 1-3) あるいは水溶性多糖類などが汎用されてい るが，これらの増粘剤には使用感触上の問題がある. それは高 分子鎖の絡み合いに起因すると考えられる曳糸性である． ${ }^{4,5}$ 化粧品を皮膚上に塗布する際に糸を曳き, いわゆるべたべた する，という好ましくない使用感触になってしまうのであ る. この問題を解決す心゙く著者らはミクロゲルの化粧品増粘 剂としての応用を進めてきた。 ${ }^{0}$ 最近著者らは逆相マイクロ エマルション重合法を用いて水膨潤性ミクロゲルの開発に 成功した。7-9)このミクロゲルは化粧品へ配合され，好ましい

株式会社資生堂 マテリアルサイエンス研究センター

于 224-8558 横浜市都筑区早㴊 2-2-1

E-mail: isamu.kaneda@to.shiseido.co.jp, Tel: +81 45-590-6053, Fax: +81 45-590-6088
使用感触を発揮しており，さらに幅広い応用が期待されてい る. 本論文では，このミクロゲルのレオロジー特性，特に降 伏応力に着目し，柔らかいコロイド粒子分散液のレオロジー 特性に関する一つの実験例として興味深い知見を得たので 報告する.

\section{2. 実験}

\section{1 水膨潤性ミクロゲルの合成}

水膨潤性ミクロゲルはジメチルアクリルアミド（DMAA）, $2-$ アリリルアミドー 2 メチル -1 プロパンスルフォン酸 (AMPS) およびメチレンビスアクリルアミド（MBA）をモノ マーとして用い，既報の方法 7)に従い，逆相マイクロエマル ション重合法により合成した. 各モノマーの共重合比は DMAA : AMPS $=80: 20$ (mol 比) であり, 架橋性モノマーで あるMBAはDMAAおよびAMPSの合計量に対して $0.1 \mathrm{~mol} \%$ の 割合で重合系に添加して合成を行った。逆相マイクロエマル ション重合系での重合終了後にアセトンによりミクロゲルを 沈殿回収し，アセトンおよびイソプロパノールで未反応モノ マーおよびその他, 乳化剤などを洗浄除去後, 減圧乾燥し, 白色粉末状のミクロゲル（MG01）を得た。収率は $90 \%$ 以上 であった. 実験に供したサンプルはすべて $3 \mathrm{mmol} / \mathrm{L}$ 塩化ナト リウム水溶液に粉末状のMG01を分散させた分散液を用いた. 


\section{3 レオロジー測定}

ストレス制御型レオメーター (MCR-300:Paar Physica) を用 いて測定した。測定治具はコーンプレート $\left(25 \mathrm{~mm}, 2^{\circ}\right)$ を 用いた。すべての測定は $25^{\circ} \mathrm{C} て ゙$ 行った.

\section{4 フリーズフラクチャー透過型電顕観察}

液体窒素を用いてミクロゲル分散液を $-220{ }^{\circ} \mathrm{C}$ で急速凍結 し，凍結サンプルの割断面のレプリカ膜を炭素および白金蒸 着により作成した。レプリカ膜を透過型電顕用グリッドに回 収し, 透過型電子顕微鏡（H-7000, 日立製作所）でフリーズ フラクチャー透過電顕（FF-TEM）像を観察した.

\section{3. 結果および考察}

\section{1 降伏応力の決定}

著者らは, 今回実験に用いたMG01の見かけ粘度と濃度の相 関についてもすでに報告しており，7,9)アインシュタインの粘 度式(1)により,このミクロゲルの形状について考察している.

$$
c[\eta]=2.5 \phi
$$

ここで $c$ は溶質濃度 $(\mathrm{g} / \mathrm{dL}),[\eta]$ は溶質の固有粘度 $(\mathrm{dL} / \mathrm{g})$, および $\phi$ は溶質の体積分率である. もし溶質分子が球形で相 互貫入しないならば， $\phi \sim 0.4$ で溶質分子の重なり合い濃度 $c^{*}$ になる. MG01の $3 \mathrm{mmol} / \mathrm{L}$ 塩化ナトリウム水溶液中での $[\eta]$ は

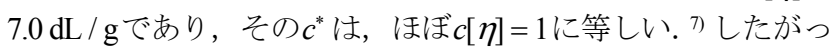
て, 少なくとも希薄領域ではMG01 は相互貫入しない球とし て振舞っていると考えられる. また, (1)式より, 溶質濃度か ら溶質の体積分率を見積ることが可能である.

一般に，コロイド濃厚分散系は塑性流動あるいは擬塑性流 動を示し, 見かけの降伏応力 $\left(\sigma_{\mathrm{a}}\right)$ を示す. しかしながら, $\sigma_{\mathrm{a}}$ は変形速度などに大きく依存し, 一義的にその值を決定す ることは困難である。本報告では, 応力一ひずみ曲線から $\sigma_{\mathrm{a}}$ を見積る方法を採用した. 寸なわち, 応力制御型レオメー ターを用い, ずり応力を一定の割合で増加させたときのひず みをモニターした。この測定から得られたずり応力とひずみ の測定值を対数プロットし, その相関直線を最小二乗法で求 め, 相関直線が屈曲する点を $\sigma_{\mathrm{a}}$ と定義して決定した. MG01 の濃度が $0.35,1.0$, および $2.0 \%$ のサンプルの結果を Fig. 1 に 示す.この濃度範囲では, いずれのサンプルも相関直線は明 確に屈曲点を示している, 寸なわち， $\sigma_{\mathrm{a}}$ を超えるずり応力が 負荷されると分散液は流動を開始していることが見てとれ る. 一方で, 動的弾性率のずり応力依存性の測定からも $\sigma$ を見 積り，この方法が妥当であるかを確認した。Fig. 2 に $0.35 \%$ お よび $2.0 \%$ のサンプルの結果を示す. いずれのサンプルも低 いずり応力下ではゲル様の挙動を示すが，あるずり応力にお いて貯蔵弾性率 $\left(G^{\prime}\right)$ が急激に低下した。この $G^{\prime}$ 変曲点が $\sigma_{\mathrm{a}}$ に対応すると考えられる. 実際に, このような動的測定か ら見積った $\sigma_{\mathrm{a}}$ はFig. 1 のS-S曲線より見積った值とよく一致す ることが確認できた.

また注目すべき点として, Fig. 2において $G^{\prime}$ が急激に低下す るずり応力の領域で損失弾性率 $\left(G^{\prime \prime}\right)$ にピークが出現する点 である.このような挙動はコロイド濃厚系によく見られる現 象であるが，これは密に充填したコロイド粒子が形成するク
ラスターの崩壊によるものであるとの報告がある。10)この点 については後に再び議論する.

$\mathrm{S}-\mathrm{S}$ 曲線から $c^{*}$ 以上の濃度のミクロゲル分散液の $\sigma_{\mathrm{a}}$ を見積 り，その濃度依存性について整理した結果がFig. 3である。な おFig. 3ではMG01の濃度を規格化した $c[\eta] て ゙$ 示した。見かけ の降伏応力 $\sigma_{\mathrm{a}}$ は $c[\eta]=2$ 程度の濃度で出現し, その後濃度依存 的に一様に増加する. しかしながら, $c[\eta]=5$ 付近を境にその 増加率は頭打ちになった。 先述の通り, 希薄領域ではこのミ クロゲルは(1)式に従うような剛体球として考えることがで きる. 重なりあい濃度 $c^{*}$ 以上の濃度においても(1) 式に従うと 仮定して $\sigma_{\mathrm{a}}$ が出現する濃度, 寸なわち $c[\eta]=2 て ゙ の \phi を(1)$ 式か ら試算すると $\phi=0.8$ 程度ということになる. 剛体球のRandom Closed Packing (RCP) の極限の体積分率は $\phi=0.64$ であり, 最密 充填状態であるとしてもせいぜい $\phi=0.78$ 程度である. この 結果は明らかに理論的に破綻している。これはミクロゲルの 柔らかさによるものであることは容易に推察できる。ミクロ ゲル粒子が孤立している希薄領域では，流体力学的にはあた

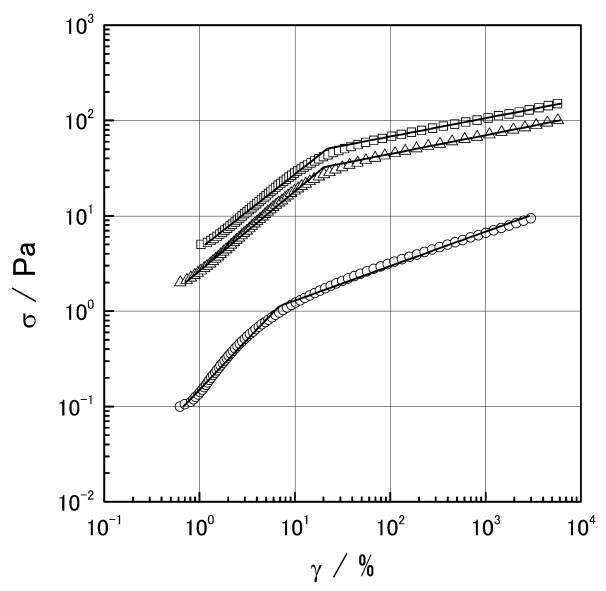

Fig. 1. The stress-strain curves of the MG01 suspensions in various concentrations. Circles, triangles, and squares denote $0.35 \%, 1.0 \%$, and $2.0 \%$ of the MG01 suspensions, respectively. Lines on these plots are correlation curves.

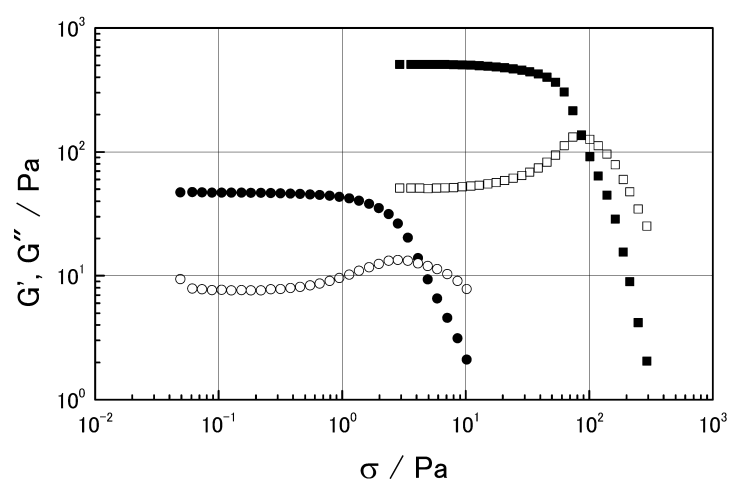

Fig. 2. The shear stress dependency of the dynamic modulus for the MG01 suspensions. Open and closed symbols denote the storage modulus $\left(G^{\prime}\right)$ and the loss modulus $\left(G^{\prime \prime}\right)$, respectively. Circles and squares denote the samples of $0.35 \%$ and $2.0 \%$, respectively. All the measurements were done at $1 \mathrm{rad} / \mathrm{s}$ and $25^{\circ} \mathrm{C}$. 
かも剛体球のように振舞うが，いったん粒子同士が接触する 濃度を超えると，ミクロゲル粒子同士は変形しながら充填し 始めると考えられる。したがってRCPの限界值である 0.64 に 到達する濃度であっても $\sigma_{\mathrm{a}}$ が見かけ上は発生しない理由は， RCPに近い状態でミクロゲル粒子が充填しても降伏応力が発 生するほどには系全体が「固化」していないことであると考 えられる。一方で動的測定の結果（Fig. 2) からわかるよう に， $\sigma_{\mathrm{a}}$ 未満の小さな外力に対しては系全体がゲル化したかの

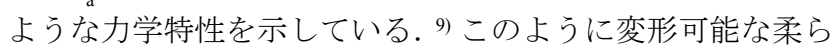
かいコロイド粒子が密に充填し見かけ上ゲル化したかのよ うなレオロジー特性を示すとき, ミクロゲル粒子はどのよう に充填するか，ということは極めて興味深い問題である。 ロイド粒子自体の力学物性がその分散液全体の力学物性に 及ぼす影響, 特にコロイド粒子自体が変形可能であるケース については, Zwanzigらによる理論モデル11) から発展させた

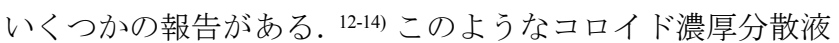
の弾性率は, コロイド粒子の動径分布 (関数), 粒子間ポテン シャル, および粒子自体の弾性率等のパラメータにより記述 可能であるとされている. 寸なわち実験的にいくつかのパラ メータを決定できれば, 動径分布関数から充填状態を推測す ることも可能である. しかしながら，MG01のような極めて 架橋密度が低く, かつ高分子電解質よりなるミクロゲルでは これらのパラメータを特定することが困難である. したがっ て, MG01のような水膨潤性のミクロゲル粒子充填による見 かけのゲル化の詳細なメカニズムの理論的解析は現時点で は難しい課題である.

\section{2 降伏応力より小さなずり応力下での変形}

ここで $\sigma_{\mathrm{a}}$ よりさいずり応力下ではこのミクロゲル分散液 はどのように変形しているかという問題を考えてみたい. 化 粧品を皮膚上で塗り伸ばす際の使用感触において，この「流 れ始める」ときの変形挙動は極めて重要であると考えられ る. 実際に化粧品の使用感触の官能評価においても降伏応力

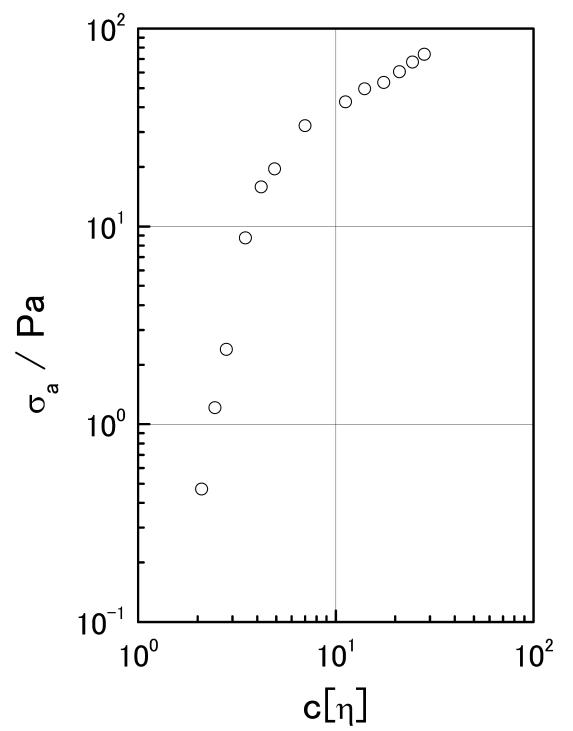

Fig. 3. The concentration dependency of the apparent yield stress for MG01 suspensions. The concentration of sample is represented as the normalized concentration, $c[\eta]$.
の大小がかなり正確に感知されているようである. Fig. 1 の S-S曲線を見てみると, $\sigma_{\mathrm{a}}$ 未満のずり応力ではその傾きがほぼ 1 に近く，見かけ上弾性変形しているように見える。また動 的測定結果（Fig. 2）も同様の傾向を示している. Fig. 2 の測 定は $1 \mathrm{rad} / \mathrm{s}$ の速度で変形させたが，この変形速度では「ゲル」 として振舞っているということになる。しかしながら，この 現象はある時間スケールでの外力負荷に対する応答を観察 しているにすぎない，そこで，実際に密に充填したミクロゲ ル分散液は微小変形下では弾性変形しているのか否かを確 認するために, クリープ曲線と動的弾性率の周波数依存性を 調べた. Fig. $4 に c[\eta]=2.45$ の濃度のサンプルのクリープ回復 曲線を示す。黒塗りのシンボル（○）は $\sigma_{\mathrm{a}}$ 未満のずり応力 (0.3 Pa) を負荷した結果であり，白抜きシンボル $(\bigcirc)$ は動的 弾性率のずり応力依存性の測定で $G^{\prime}$ と $G^{\prime \prime}$ が交差する点での ずり応力を負荷した結果である．いずれもずり応力は 60 秒間 負荷した後，ずり応力を開放し回復を観察した．またずり応 力負荷 60 秒後のひずみを最大ひずみ $\left(\gamma_{\text {max }}\right)$ として、測定さ れたひずみ值を $\gamma_{\text {max }}$ で除した $\gamma / \gamma_{\text {max }}$ として示している. Fig. 4 から, 見かけの降伏応力 $\sigma_{\mathrm{a}}$ 未満の微小なずり応力下において もクリープ現象が観察されており，この濃度のMG01分散液 は微小変形下でも弾性変形ではなく，「流動」していること が明らかである。一方で、大きなずり応力下では完全に流動 してしまうこともわかる. この $\sigma<\sigma_{\mathrm{a}}$ でのクリープ曲線を マックスウエルモデルとフォークトモデルが直列した四要 素力学モデル (Burger model) を用いて解析を試みた. 四要素 力学モデルのクリープフェーズのコンプライアンス $J(t)$ は (2)式のように書き表せる.

$$
J(t)=J_{0}+J_{m}\left(1-e^{t / \lambda}\right)+t / \eta_{0}
$$

ここで $J_{0}$ は瞬間コンプライアンス, $J_{m}$ は最大コンプライアン ス, $\lambda$ は遅延時間, および $\eta_{0}$ はゼロずり粘度である. 測定デー

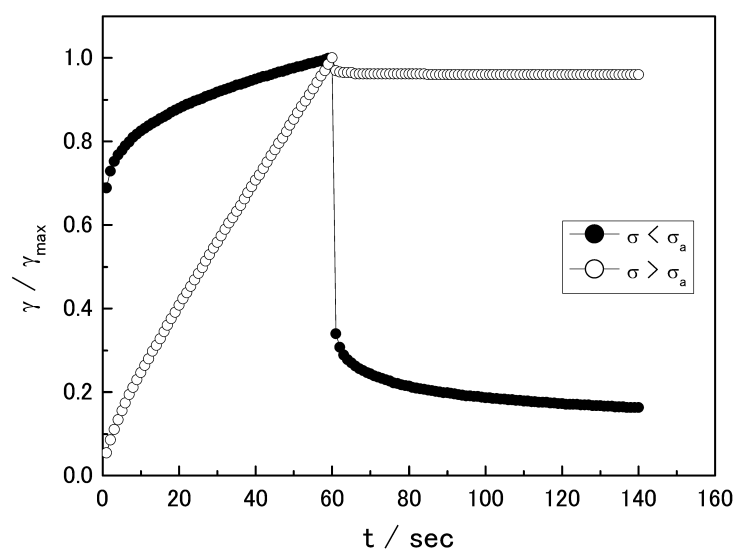

Fig. 4. The creep-recovery curves for the MG01 aqueous suspension $(c[\eta]=2.45)$ applied various shear stresses. Applied shear stresses were $0.3 \mathrm{~Pa}$ and $7 \mathrm{~Pa}$ for the closed and open symbols, respectively. The applied stress values for the measurements are represented the normalized values divided by the maximum strain, $\gamma$ max. 
夕を用い(2)式から入を求めたところ, 10-15秒程度の值が得ら れ, 非常にゆっくりとした緩和機構の存在が示唆された. こ の非常にゆっくりした緩和機構について, 遅い変形速度での 応答について調べるために比較的長周期側での動的弾性率の 角速度 $(\omega)$ 依存性を調べた. MG01の $c[\eta]=2.45(c=0.35 \%)$ の サンプルに一定ずり応力 $(0.1 \mathrm{~Pa})$ 下で $\omega=0.01-100 \mathrm{rad} / \mathrm{s}$ の範 囲で測定した動的弾性率の結果を示寸. $G^{\prime}$ は弱い周波数依存 性を示し，長周期側に向かってわずかに減少している. 一方 $G^{\prime \prime}$ は測定周波数範囲の最も長周期側で大きく上昇している.

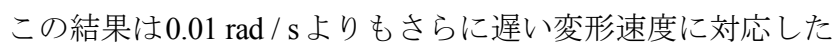
きわめて遅い緩和（100秒のオーダー）があることを示唆し

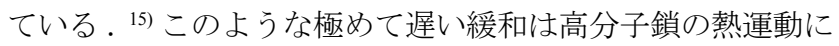
よる緩和ではなく, おそらくは密に充填して, クラスターを 形成しているミクロゲル粒子の, 外力による擾乱に対する再 配置を観察しているものと考えられる. ${ }^{10)}$ その証拠として動 的弾性率のずり応力依存性の測定結果（Fig. 3）においても, このようなコロイド粒子によるクラスターの崩壊に特徴的 な $G^{\prime \prime}$ 挙動があったことは先述したとおりである。ここでク リープ曲線の解析結果と動的測定の結果から得られた緩和 時間に一桁以上の差異があることの理由については現時点 では明確な説明ができない，ただ一つ言えることはクリープ 曲線の解析の精度に問題がある可能性があるということで ある. 今回は単純な四要素モデルでフィッティングを行った が, 実在のサンプルの力学物性はこのような単純なモデルで は到底記述できない. またレオメーターの応答速度の問題で ずり応力負荷直後のデータの信頼性が低いこと, さらにク リープフェーズも 60 秒と比較的短い時間での測定結果であ り，この時間内に定常流に達しているか否かは不明である. 今後クリープ測定についてはさらなる詳細な実験が必要で あると考えている.

\section{3 水膨潤性ミクロゲルの充填状態の直接観察}

これまでにレオロジー測定結果からこのミクロゲルの充 填状態について考察してきた. ここで実際のミクロゲル粒子 の膨潤状態あるいは充填状態を確認するために, フリーズフ

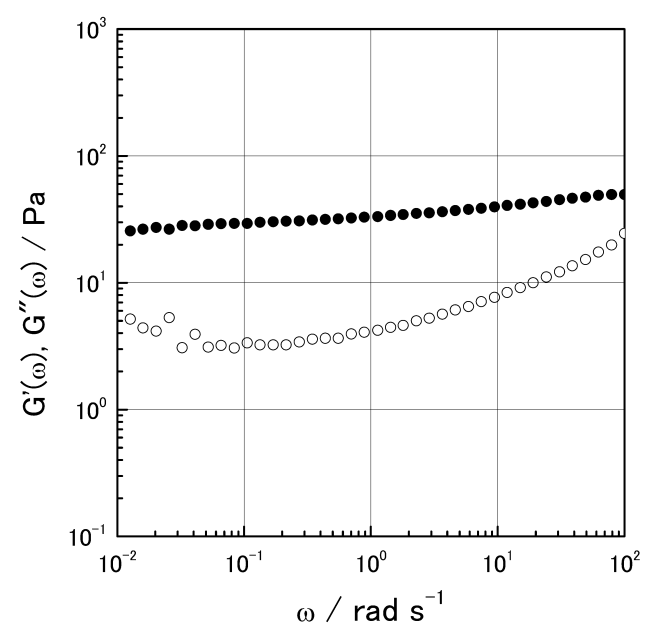

Fig. 5. The frequency dependency of the dynamic modulus of the MG01 suspension $(c[\eta]=2.45)$. Closed and open symbols denote $G^{\prime}(\omega)$ and $G^{\prime \prime}(\omega)$, respectively.
ラクチャー透過型電子顕微鏡（FF-TEM）観察を試みた。一 般に TEM観察はサンプルチャンバー内を低圧にする必要が あり，溶媒を含むゲルの膨潤状態を観察することは困難で ある. そこで本研究ではFF-TEMの手法を用い, 急速凍結し たミクロゲル分散液サンプルの割断面のテクスチャーを 炭素一白金蒸着によりレプリカ膜として写し取り，これを TEMで観察した。この方法によれば溶媒で膨潤したミクロゲ ルのスナップショットを観察可能であると考えられる. Fig. 6 に観察例を示寸.このサンプルは $c[\eta]=3(c=0.43 \%)$ の濃度 のサンプルである．画像よりこのミクロゲルは確かに球形に 膨潤しており，かつそのサイズはよく揃つている．またミク ロゲル粒子は密に充填している様子が見てとれる．特筆す心゙ きことは、割断面の平面上にミクロゲルがきれいに並んでい るということである。このことは膨潤状態にあって，ミクロ ゲル粒子は層状に配列しており，それぞれの粒子の熱運動は ほとんど凍結されていると思われる. 外力による変形挙動 は，以下のような描像を描くことができる．まず $\sigma_{\mathrm{a}}$ 未満の外 力に対してはミクロゲル粒子自体の変形・回復を伴いながら ゆっくりと流動する．一方， $\sigma_{\mathrm{a}}$ を上回る外力により粒子が配 列している層間が滑ることで急激に流動すると考えられる. Cristはコロイド濃厚系, いわゆるコロイドガラスあるいはコ ロイド結晶の降伏応力を考察するモデルとしてこのような 層状モデルを提唱しているが，16)まさに現実の実験例として 示された興味深い例であると考えられる。

\section{4 柔らかいコロイド粒子充填系の変形挙動}

ここまで逆相マイクロエマルション重合法で重合された 水膨潤性ミクロゲルの準希薄系のレオロジー挙動について 降伏応力に焦点を絞って論じてきた．現時点での未解決問題 としては，極めて膨潤率の高いこのようなミクロゲルが $c^{*}$ を 超える濃度でどのように膨潤し，充填されていくか，という 問題である.この問題について今回得られた実験結果に基づ いて現象論的な立場で考察してみる. 本報ではデータを示さ

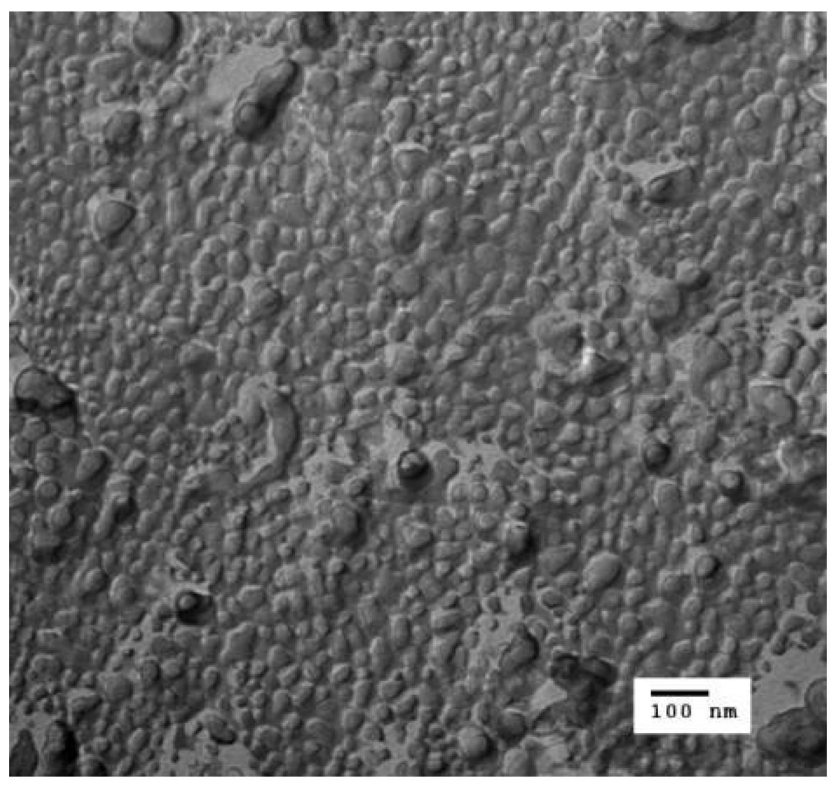

Fig. 6. The freeze-fracture TEM image of the MG01 suspension $(c[\eta]=3.0)$. 
ないが, MG01の高濃度分散液のFF-TEM像を詳細に観察する と，一つ一つのミクロゲル粒子のサイズが小さくなっていく 傾向が見られる.このような現象から推察されることは, 溶 質としてのミクロゲル粒子数が増えていくと，それぞれのミ クロゲル粒子は脱膨潤しながら, さらに密に充填していくの ではないかと考えられる。もしミクロゲル粒子濃度の増加に より，ミクロゲル粒子それぞれが脱膨潤するとすれば，その ドライビングフォースは何であるか, 言い換えれば, 熱力学 的安定状態（ゲルの膨潤平衡状態）のシフトは，どのような メカニズムで生じるのか, という問題に直面することになる.

また，ミクロゲル (ポリマー) の濃厚状態のレオロジー挙 動解析も, 化粧品の応用研究という観点で考えると重要な課 題である. なぜなら，化粧品，特にスキンケア製品では，製 剂を皮膚上に塗布した後に揮発性溶媒（水・アルコールなど） は皮膚状から揮発し, 結果的に不揮発性の原料は皮膚上に残 留する（高分子量の成分は経皮吸収されない）。言い換えれ ば，高分子原料は皮膚上で濃縮されることになる. 冒頭に述 べたように，化粧品の使用感触は，その製品の価值を左右す る重要なファクターであるが，それは製剤適用時の流動特性 のみならず，このように皮膚上に残留した「濃縮された」製 剂の力学物性と強い相関があることが予想される.

柔らかいミクロゲル（コロイド粒子）の準希薄分散液のレ オロジーについては，有機溶媒に膨潤するミクロゲルに関す る研究成果がいくつか報告されているが，10,17-19) 高分子電解 質からなる水膨潤性で, かつ, 形状がある程度制御された （球形）ミクロゲルに関するこの種の報告は, 寒天を用いた 「硬い」ミクロゲルの報告 ${ }^{20)}$ が見られる程度である（ポリア クリル酸のミクロゲルに関する報告 ${ }^{1-3)}$ については, これら のミクロゲルの膨潤状態でのミクロゲルの形状に関する記 載はない).

本論文では制限された空間内，すなわち逆相マイクロエマ ルション相で重合された形状がコントロールされた水膨潤 性ミクロゲルを用いて, その準希薄分散液のレオロジー挙動 を降伏応力に注目して行ったいくつかの実験結果を紹介し た. 柔らかいコロイド粒子の充填状態での物理化学的研究 は，これまで述べてきたとおり多くの未解決問題を残してお り, 学術的興味はもちろんのこと, 応用研究としても今後注 目すべき課題であると考えられる.

\section{4. 結言}

逆相マイクロエマルション重合法で重合され, 極めて架橋 密度の低い柔らかい水膨潤性ミクロゲルの準希薄分散液の レオロジー挙動を降伏応力に着目して詳細に調べた.このミ クロゲル分散液は基本的に流動する「流体ゲル（Fluid Gel）」 であり、その流動挙動は変形速度に大きく影響されることが わかった. 見かけ上あたかも容器内を張り巡らされた網目構
造を持つかのようなゲル様になった濃厚分散液にもクリー プ現象が観察され，その柔らかさのため、このミクロゲルは 高充填状態でも外力により流動することがわかった. FF-TEM の手法を用い，このような水膨潤性ミクロゲルの膨潤状態あ るいは充填状態の直接観察に成功した. 密に充填したミクロ ゲル粒子は層状に配列しており，その変形は、この層のす心゙ りが関連していることが示唆された。

\section{5. 謝辞}

FF-TEM観察において名古屋大学国際物質研究センターの 今栄東洋子教授に丁寧なご指導をいただいたことを感謝い たします。

\section{REFERENCES}

1) Ketz Jr. RJ, Prud'homme RK, Graessley WW, Rheol Acta, 27, 531 (1988).

2) Nae HN, Reichert WW, Rheol Acta, 31, 351 (1992).

3) Islam MT, Rodriguez-Hornedo N, Ciotti S, Ackermann C, Pharmaceutical Research, 21, 1192 (2004).

4) Nakagawa T, Bull Chem Soc Japan, 25 (2), 88 (1952).

5) Nakagawa T, Bull Chem Soc Japan, 25 (2), 93 (1952).

6) Kaneda I, Yanaki T, Nihon Reoroji Gakkaishi, 30, 89 (2002).

7) Kaneda I, Sogabe A, Nakajima H, J Colloid Interface Sci, 275, 450 (2004).

8) Kaneda I, Sogabe A, Miyazawa K, Nakajima H, J Soc Cosmet Chem Jpn, in press.

9) Kaneda I, Sogabe A, Colloids Surf A, 270-271, 163 (2005).

10) Fridrikh $S$, Raquois $C$, Tassin JF, Rezaiguia $S$, J Chem Phys, 93, 941 (1996).

11) Zanzig R, Mountain RD, J Chem Phys, 43, 4464 (1965).

12) Goddard JD, J Non-Newtonian Fluid Mech, 2, 169 (1977).

13) Snabre P, Mills P, Colloids Surf, A 152, 79 (1996).

14) Snabre P, Mills P, J Phys III, 6, 1835 (1999).

15) Gisler T, Ball RC, Weitz DA, Phys Review Lett, 82, 1064 (1999).

16) Crist B, "Structure and Properties of Polymers, Materials Science and Technology", vol. 12, Thomas EL (ed), (1993) VCH Publishers, New York.

17) Wolfe MS, Scopazzi C, J Colloid Interface Sci, 133, 265 (1989).

18) Quemada D, Eur Phys J AP, 1, 119 (1998).

19) Berli CL A, Quemada D, Langmuir, 16, 7974 (2000).

20) Adams S, Frith WJ, Stokes JR, J Rheol, 48 (6), 1195 (2004). 